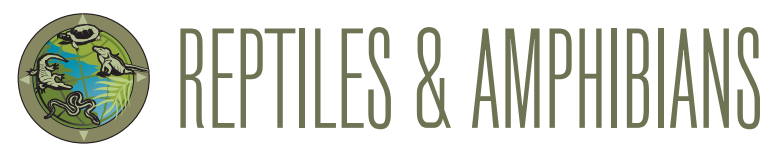

\title{
Observations of Feeding Behavior and a Note on Clutch Size in Wall's Keelback, Herpetoreas xenura (Wall 1907) (Squamata: Natricidae)
}

Lal Muansanga, L.H. Laltlanhlui, Lalbiakzuala, Yash Singh Rathee, and H.T. Lalremsanga

Department of Zoology, Mizoram University, Aizawl, 796004, Mizoram, India (muanapunte16@gmail.com)

W all's Keelback (Herpetoreas xenura) ranges from northeastern India (Assam, Meghalaya, Nagaland and Mizoram) south into Bangladesh and Myanmar (Whitaker and Captain 2008; Das 2018; Uetz et al. 2020). Nothing is known about the diet and reproduction of this species. Herein we document two instances of predation and provide information on clutch and egg size.

At 2145 h on 27 July 2020, we encountered a female Herpetoreas xenura (SVL $467 \mathrm{~mm}$ ) feeding on a female Assam Forest Frog (Hydrophylax leptoglossa) (total length $263 \mathrm{~mm}$ ) on the edge of a pool surrounded by secondary forest used as a Betel Nut (Areca catechu) plantation at N. Hlimen, Miozram, India $\left(24.20198^{\circ} \mathrm{N}, 92.80833^{\circ} \mathrm{E}\right.$; elev. $577 \mathrm{~m}$ asl). The snake ambushed the frog, grasped its head (Fig. 1), and struggled with

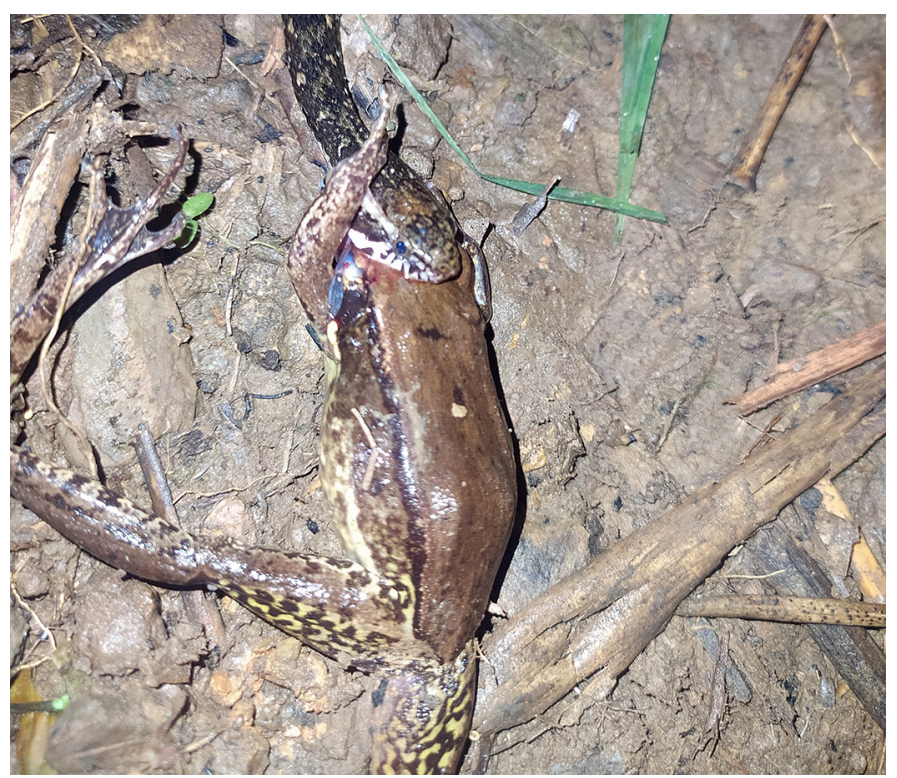

Fig. 1. A female Wall's Keelback (Herpetoreas xenura) feeding on a female Assam Forest Frog (Hydrophylax leptoglossa). Photograph by Lal Muansanga.

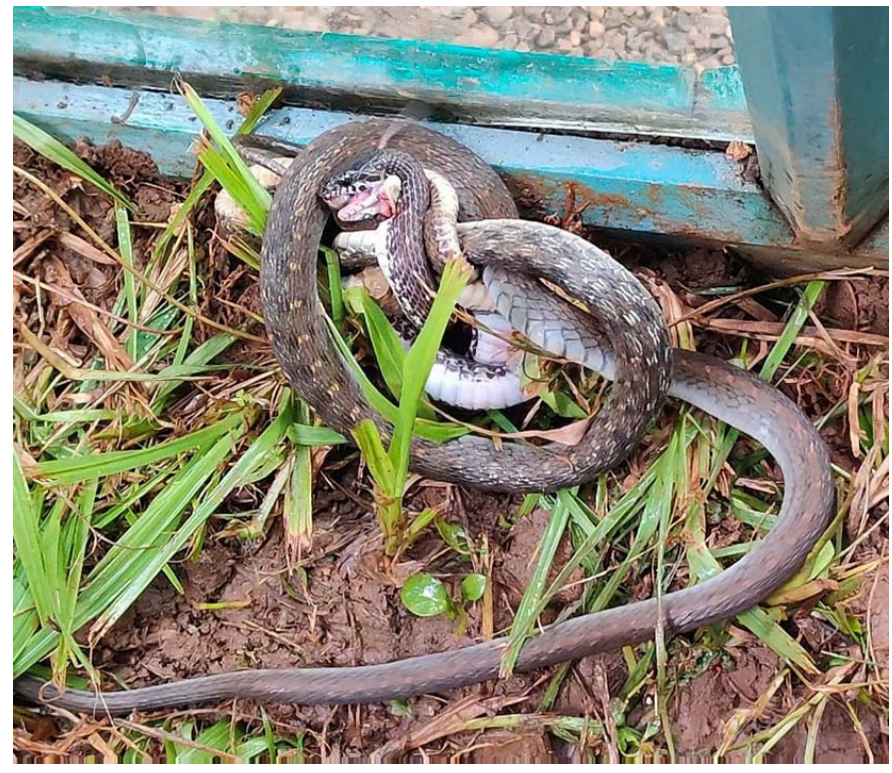

Fig. 2. A female Wall's Keelback (Herpetoreas xenura) feeding on a male Orange-collared Keelback (Rhabdophis himalayanus). Photograph by Yash Singh Rathee.

it for 9 min before swallowing it. Elapsed time from strike to complete ingestion was about 18 mins. We did not disturb the snake while it was feeding but collected it for morphological measurements before releasing it into suitable habitat on 30 July 2020.

At $0715 \mathrm{~h}$ on 13 August 2020, we encountered another female $H$. xenura (SVL $488 \mathrm{~mm}$ ) feeding on a male Orangecollared Keelback (Rhabdophis himalayanus) (SVL ca. 350 $\mathrm{mm}$ ) adjacent to a residence in Umroi, Meghalaya, India $\left(25.68624^{\circ} \mathrm{N}, 91.93215^{\circ} \mathrm{E}\right.$; elev. $957 \mathrm{~m}$ asl). At the time of the initial observation, the two snakes were coiled around each other and only later did we notice that the $H$. xenura was engulfing the head of the $R$. himalayanus (Fig. 2), which had 


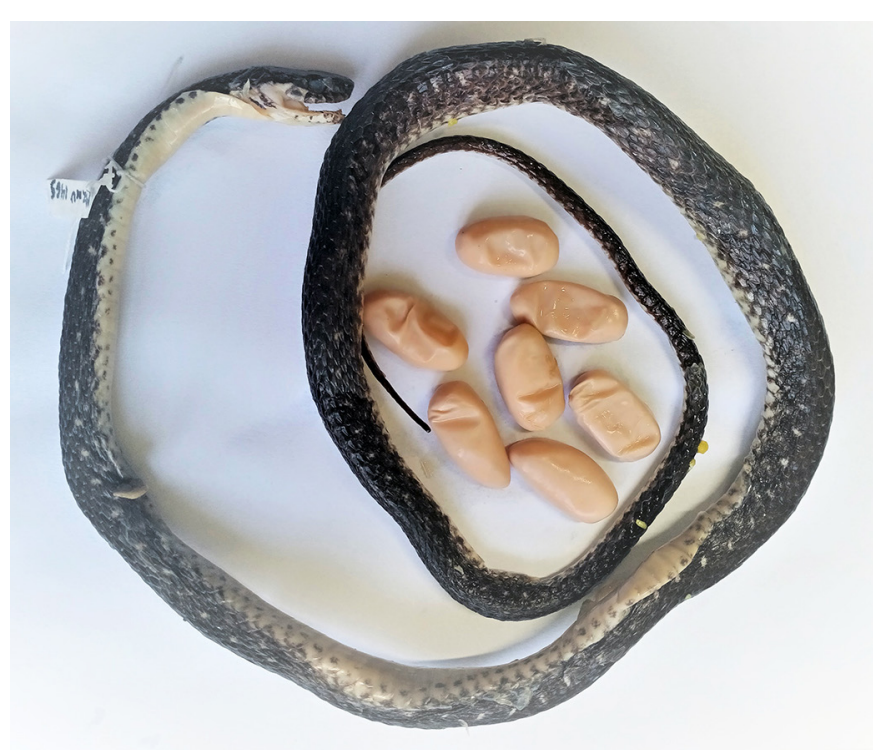

Fig. 3. A road-killed female Wall's Keelback (Herpetoreas xenura) with seven eggs recovered from the oviduct. Photograph by L.H. Laltlanhlui.

suffocated. Because we did not see the initial strike, we were unable to determine the elapsed time from strike to complete ingestion. The snake was not disturbed and escaped into nearby secondary forest.

At 2030 h on 15 July 2015, we collected a road-killed female H. xenura (SVL $562 \mathrm{~mm}$ ) at Sihphir, Aizawl, Mizoram, India $\left(23.809972^{\circ} \mathrm{N}, 92.749056^{\circ} \mathrm{E}\right.$; elev. $1,089 \mathrm{~m}$ asl).
Dissection revealed a clutch of seven eggs (Fig. 3); mean length and width of the eggs were $24.22 \mathrm{~mm}(22.20-25.81 \mathrm{~mm})$ and $12.68 \mathrm{~mm}(12.16-13.00 \mathrm{~mm})$, respectively. The snake along with eggs were preserved in $10 \%$ buffered formalin and catalogued in the Departmental Museum of Zoology, Mizoram University (MZMU 1465).

\section{Acknowledgements}

The authors are sincerely thankful to the Office of the Chief Wildlife Warden, PCCF (WL), Tuikhuahtlang, Aizawl, Government of Mizoram, for permission to collect the herpetofauna of Mizoram; and the Additional Principal Chief Conservator of Forest, Wildlife and Chief Wildlife Warden, Meghalaya, for permission to collect snakes in Umroi, Meghalaya. We also thank the Defence Research Development Organisation, Ministry of Defence (Sanction no. DFTM/07/3606/NESTC/ABR/M/P-01) and the Department of Biotechnology, New Delhi (No. DBT-NER/ $\mathrm{AAB} / 64 / 2017)$ for financial support.

\section{Literature Cited}

Das, I. 2018. A Naturalist's Guide to the Snakes of South-east Asia. Malaysia, Singapore, Thailand, Myanmar, Borneo, Sumatra, Java and Bali. $2^{\text {nd }}$ Edition. John Beaufoy Publishing Ltd., Oxford, UK.

Uetz, P., P. Freed, and J. Hošek (eds.). 2020. The Reptile Database. https://reptiledatabase.reptarium.cz/species?genus=Herpetoreas\&species=xenura\&search_ param $=\% 28 \% 28$ search $\% 3 \mathrm{D} \% 27$ Herpetoreas + xenura $\% 27 \% 29 \% 29$.

Whitaker, R. and A. Captain. 2004. Snakes of India. The Field Guide. Draco Books, Chennai, India. 